\title{
Effect of the North Atlantic Oscillation on the Pattern of Lake Ice Phenology in Poland
}

\author{
Dariusz WRZESIŃSKI ${ }^{1}$, Adam CHOIŃSKI ${ }^{1}$, Mariusz PTAK ${ }^{1}$, \\ and Rajmund SKOWRON ${ }^{2}$ \\ ${ }^{1}$ Institute of Physical Geography and Environmental Planning, \\ Adam Mickiewicz University, Poznań, Poland; \\ e-mails: darwrze@amu.edu.pl, choinski@amu.edu.pl, \\ marp114@wp.pl (corresponding author) \\ ${ }^{2}$ Department of Hydrology and Water Management, \\ Nicolaus Copernicus University, Toruń, Poland; \\ e-mail: rskowron@umk.pl
}

\begin{abstract}
This paper presents an analysis of the influence of the North Atlantic Oscillation on the pattern of lake ice phenology in Poland. The research embraced 22 lakes in Poland over the period 1961-2010. Strong relations were found to hold between NAO and individual characteristics of ice phenology. In a negative NAO phase, one can observe a later appearance of ice phenomena and ice cover compared with the average values, ice cover persisting even 30 days longer and being thicker even by more than $10 \mathrm{~cm}$. In turn, in a positive NAO phase the duration of ice phenomena and ice cover is shorter, the cover being less thick and solid. The observed spatial differences in the effect of NAO on the pattern of ice phenomena in Poland show this matter to be fairly complex. The most significant factor changes in climatic conditions, which manifest themselves in the continentality of the climate growing eastwards.
\end{abstract}

Key words: climate change, ice cover, teleconnections.

Ownership: Institute of Geophysics, Polish Academy of Sciences;

(C) 2015 Wrzesiński et al. This is an open access article distributed under the Creative Commons Attribution-NonCommercial-NoDerivs license,

http://creativecommons.org/licenses/by-nc-nd/3.0/. 


\section{INTRODUCTION}

Of key significance for the operation of lakes in the middle and high geographical latitudes is thermal seasonality connected with ice phenology. The process of ice formation itself is well known and follows from an exchange of heat between a water mass and the surroundings. Its rate and scale are determined by many factors, among which Majewski (2007) lists air temperature, water temperature, water depth, etc. As a result of the appearance of ice, considerable changes take place in the operation of lake ecosystems that follow from the isolation of water from external factors (no waving, reduced light, etc.). Those issues are discussed in many works, a survey of which has been made by Gerten and Adrian (2000). An effect of the observed changes in climatic conditions is a shift in thermal seasons of the year (Thomson 2009) leading, among other things, to disturbances in the ice regime of lakes. Long-term observations show that the ice season tends to shorten and the thickness of ice cover to diminish (Futter 2003, Korhonen 2006, Jensen et al. 2007, Leppäranta 2014). The interpretation of the observed trends should accommodate the cyclicity of macro-scale factors embracing atmospheric and oceanic circulation (Brown and Duguay 2010). What exerts a strong influence on the climatic conditions in Europe is the North Atlantic Oscillation (NAO). Its effect is visible in the pattern of climatic and hydrological characteristics, and has been documented in several works on precipitation (Bednorz 2011, Castro et al. 2011), air temperature (Scaife et al. 2008, Heape et al. 2013), and river runoff (Pociask-Karteczka 2006, Wrzesiński and Paluszkiewicz 2011). The effect of the NAO has also been proved with reference to lake ice phenology (Maher et al. 2005, George 2007, Weyhenmeyer 2009, Soja et al. 2014, Sharov et al. 2014).

This paper seeks to establish spatial differences in the parameters of lake ice phenology in Poland in average conditions and under the influence of the variable intensity of atmospheric circulation in the North Atlantic sector. The research conducted was designed to show that the level of intensity of the North Atlantic Oscillation caused significant differences in the ice phenology of lakes in Poland. The study was carried out on the lakes of northern Poland, i.e., a lakeland area embraced by the last Scandinavian glaciation. No detailed analysis of this issue has so far been made for such a large set of lakes in this part of Europe and for a 50-year-long observation period. Earlier studies of the effect of the North Atlantic Oscillation on the parameters of lake ice phenology in Poland only focused on small groups of lakes (Girjatowicz 2003, Wrzesiński et al. 2013), four and three, respectively. The results obtained in those works reveal a strong link between this circulation and lake ice phenology, and encourage making such an analysis for a larger set of lakes. 


\section{MATERIAL AND METHODS}

Observations of ice phenomena on lakes in Poland started as early as the 19th century. They mostly focused on the thickness of ice cover, more rarely on the start and end of its occurrence. Such measurements were performed for the purposes of fishing trade, but this material was scattered and nonsystematic, hence of little scientific worth (Skowron 2011). Constant observations of ice phenomena are conducted by the Institute of Meteorology and Water Management (IMGW). Records are made of the dates of appearance of ice phenomena (the presence of ice in water in any form: shore ice, frazil ice), the appearance of ice cover, its breakup, the disappearance of ice phenomena, and the thickness of ice cover. At present, observations of the characteristics of ice phenology are conducted on 22 out of the country's 7000 lakes (of 1 ha and more in area) (Fig. 1), the morphometric parameters of which are presented in Table 1. This paper offers an analysis of the pattern of ice phenomena on those lakes in the period 1961-2010.

An analysis was made of ten parameters of lake ice phenology: the start and the end of ice phenomena (the first and the last day when any form of ice in water, identified with shore ice, was recorded) the start and the end of ice cover (the first and the last day when the lake surface in the observer's arc of visibility was completely covered with ice), the duration of ice phenomena and ice cover (the dates when shore ice and ice cover were observed for the first and the last time), ice cover thickness measured every five days, and the date of its maximum thickness (in the case of five lakes, no informa-

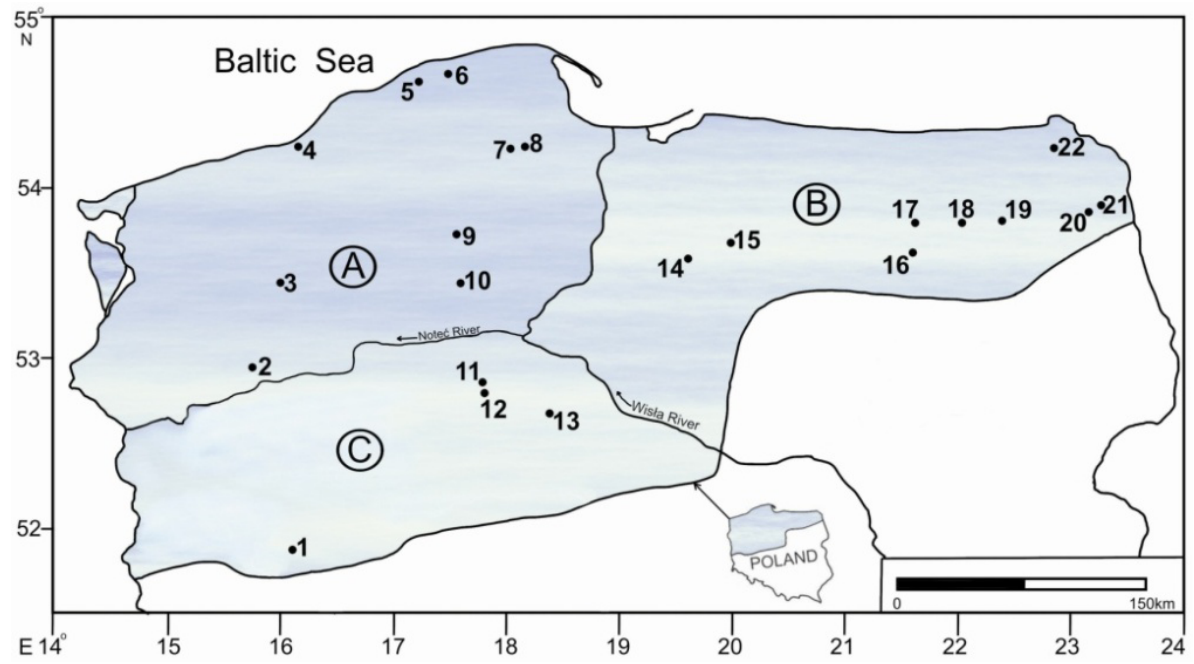

Fig. 1. Location of the studied lakes (numbering in accordance with Table 1), marked area is that of Last Glaciation; A - Pomeranian Lakeland, B - Mazurian Lakeland, C - Wielkopolska-Kujavia Lakeland. 
Table 1

Morphometric data of the studied lakes

\begin{tabular}{|c|l|r|r|r|r|}
\hline No. & \multicolumn{1}{|c|}{ Lake } & $\begin{array}{c}\text { Area } \\
{[\text { ha] }}\end{array}$ & $\begin{array}{c}\text { Volume } \\
{\left[\text { thous. }{ }^{3}\right]}\end{array}$ & $\begin{array}{c}\text { Depth average } \\
{[\mathrm{m}]}\end{array}$ & $\begin{array}{c}\text { Altitude } \\
{[\mathrm{m} \text { a.s.1.] }}\end{array}$ \\
\hline 1 & Sławskie & 822.5 & 42664.8 & 5.2 & 56.9 \\
2 & Osiek & 514.0 & 50065.0 & 9.3 & 51.4 \\
3 & Lubie & 1487.5 & 169880.5 & 11.6 & 95.4 \\
4 & Jamno & 2231.5 & 31528 & 1.4 & 0.1 \\
5 & Gardno & 2337.5 & 30950.5 & 1.3 & 0.3 \\
6 & Łebsko & 7080.0 & 117521 & 1.6 & 0.2 \\
7 & Raduńskie Górne & 362.5 & 60158.7 & 15.5 & 161.6 \\
8 & Ostrzyckie & 296.0 & 20785.2 & 6.7 & 160.1 \\
9 & Charzykowskie & 1336.0 & 134533.2 & 9.8 & 120 \\
10 & Sępoleńskie & 157.5 & 7501.6 & 4.8 & 112.8 \\
11 & Żninskie Duże & 420.5 & 29492.6 & 6.8 & 77.7 \\
12 & Biskupińskie & 107.0 & 6397.2 & 5.5 & 78.6 \\
13 & Gopło & 2121.5 & 78497.0 & 3.6 & 77.0 \\
14 & Jeziorak & 3152.5 & 141594.2 & 4.1 & 99.2 \\
15 & Drwęckie & 780.0 & 50140.1 & 5.7 & 94.8 \\
16 & Nidzkie & 1750.0 & 113872.3 & 6.2 & 117.9 \\
17 & Mikołajskie & 424.0 & 55739.7 & 11.2 & 115.7 \\
18 & Orzysz & 1012.5 & 75326.2 & 6.6 & 120.0 \\
19 & Ełckie & 385.0 & 57420.3 & 15.0 & 119.9 \\
20 & Studzieniczne & 244.0 & 22073.6 & 8.7 & 123.4 \\
21 & Serwy & 438.5 & 67181.5 & 14.1 & 126.8 \\
22 & Hańcza & 291.5 & 120364.1 & 38.7 & 227.3 \\
\hline
\end{tabular}

tion was obtained about appearance of maximum ice thickness). On the basis of those observations it was possible to determine ice cover durability, understood as the proportion of the number of days with ice cover to the number of days between the first and the last day with ice cover [\%], and its duration, which means the proportion of the number of days with ice cover in the entire period of ice phenomena, i.e., from the first to the last day when those phenomena could be observed (e.g., shore ice, ice floe, etc.) [\%].

In order to determine the dependence of changes in the ice phenology parameters on the intensity of the North Atlantic Oscillation, Pearson's coefficient of linear correlation was calculated $(r)$, the correlation holding between the ice phenology parameters under study and Hurrell's winter NAO DJFM $_{\text {in- }}$ dex. In the case of the start of ice phenomena and the formation of ice cover, also calculated were coefficients of correlation with seasonal NAO indices from the periods September-November $\left(\mathrm{NAO}_{\mathrm{SON}}\right)$, October-December $\left(\mathrm{NAO}_{\mathrm{OND}}\right)$, and November-January $\left(\mathrm{NAO}_{\mathrm{NDJ}}\right)$. 
Changes in the parameters of ice phenomena on the examined lakes in a positive and a negative $\mathrm{NAO}_{\text {DJFM }}$ phase were determined on the basis of how those parameters differed from the average values from the years 1961-2010. The average values of those parameters were calculated for years with high $\left(\mathrm{NAO}_{\text {DJFM }}>1.63\right)$ and low $\left(\mathrm{NAO}_{\text {DJFM }}<-1.09\right)$ values of the winter $\mathrm{NAO}_{\text {DJFM }}$ index. Those figures correspond to the first and third quartiles from the entire set of $\mathrm{NAO}_{\text {DJFM }}$ indices in the years 1961-2010. The statistical significance of those differences was examined using the $T$-test for stratified samples. Each time the hypothesis tested was $\mathrm{H}_{0}: \mu=\mu_{0}$ of the equality of the expected values against $\mathrm{H}_{1}: \mu \neq \mu_{0}$. The rejection of the hypothesis allowed a conclusion about there being significant differences between the mean parameters of ice phenomena observed in the different $\mathrm{NAO}_{\text {DJFM }}$ phases and the average values. To verify the hypothesis, use was made of a test for a small sample based on Student's $t$-distribution, with $n-1$ degrees of freedom:

$$
t=\left|\frac{\bar{x}-\mu_{0}}{\sigma} \sqrt{n}\right|,
$$

where $n$ is the sample size, $\sigma$ the standard deviation, $x$ the mean of the sample, and $\mu_{0}$ the mean of the population.

In this paper use was made of the winter NAO index (NAO $\left.{ }_{\text {DJFM }}\right)$ and seasonal NAO indices worked out by Hurrell (1995).

To present spatial differences in changes in the parameters of lake ice phenology, the Surfer 10 Program (GoldenSoftware) was employed, and isolines were drawn using the kriging procedure.

\section{RESULTS AND DISCUSSION}

\subsection{Average parameters of lake ice phenology in Poland in the years 1961-2010}

On the lakes under study, ice phenomena begin in mid-December. The earliest ones start in the first half on the lakes in the Wielkopolska-Kujavia Lakeland, the western part of the Mazurian Lakeland, and the coastal lakes Lebsko and Gardno (Fig. 2a). On most lakes of the Pomeranian and Mazurian Lakelands, ice phenomena begin in the last decade of December, and in the case of Lake Lubie, in the first decade of January.

The spatial distribution of the dates of ice cover formation is similar, but about 10 days later (Fig. 2b). On the lakes of the central part of the lakeland zone and on the coast, ice cover appears on average in the last decade of December, and on most lakes of the Pomeranian and Mazurian Lakelands, in the first decade of January, appearing the latest on Lake Lubie (11 January). 

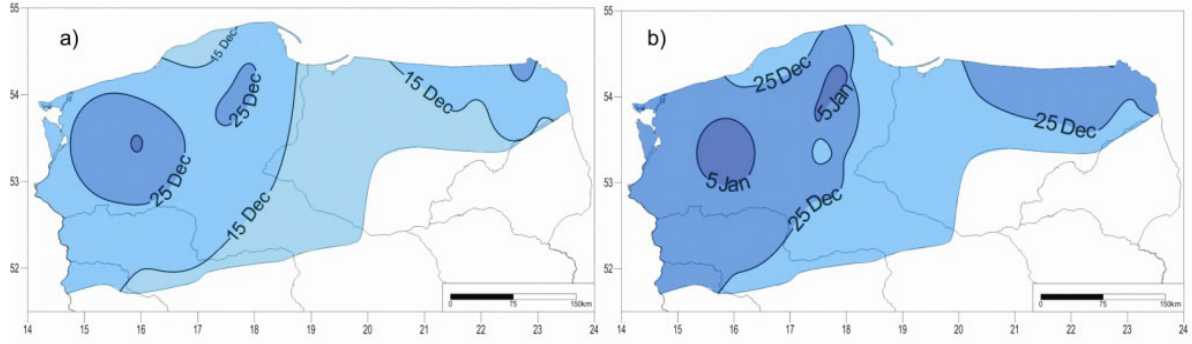

Fig. 2. Spatial differences in the dates of the start of: (a) ice phenomena, and (b) ice cover.
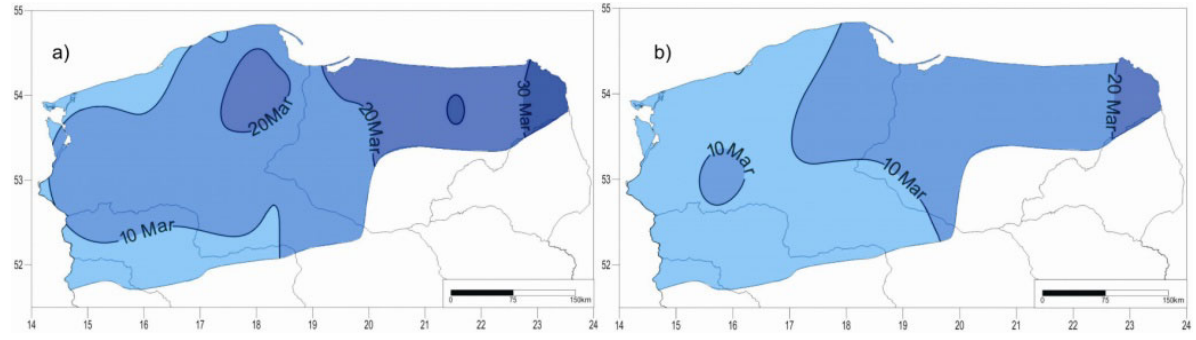

Fig. 3. Spatial differences in the dates of the end of: (a) ice phenomena, and (b) ice cover.

What is highly characteristic is the spatial distribution of the date of the end of ice phenomena and ice cover. Those ice phenomenology parameters are the earliest on lakes in the western part of the study area: in the case of ice cover, in late February and early March (Fig. 3b), and in case of ice phenomena, in the first decade of March (Fig. 3a). Those dates are ever later in the easterly direction. In the eastern part of the Mazurian Lakeland, ice cover usually disappears in the third decade of March, and ice phenomena in the first decade of April.

The spatial distributions of the duration of ice phenomena and ice cover are similar. Ice phenomena last the shortest (under 70 days) on lakes in the western part of the area and near the sea, and the longest (over 100 days) in the east; $c f$. Fig. 4a. As to the ice cover, it persists for less than 60 days on the lakes in the west, and over 80 days in the east; $c f$. Fig. $4 \mathrm{~b}$.

Also the mean maximum thickness of ice cover on lakes grows eastwards, from about $20 \mathrm{~cm}$ in the western part of the area to over $30 \mathrm{~cm}$ in the east; $c f$. Fig. 5a. Spatial differences are wider in the case of the date when it attains its maximum thickness. This occurs the earliest on the lakes of the Wielkopolska-Kujavia Lakeland and on coastal lakes (late January and early February); $c f$. Fig. 5b. For most lakes this date falls in mid-February, and for those in the eastern part of the area, in the third decade of February. 

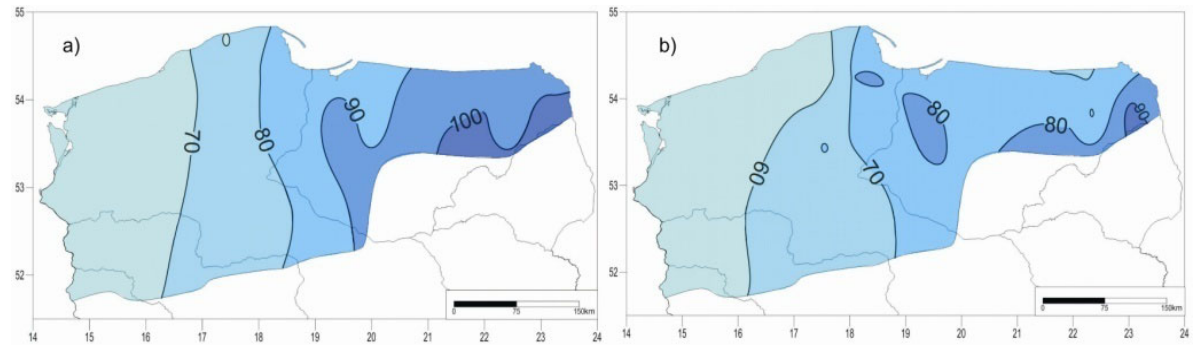

Fig. 4. Spatial differences in the duration of: (a) ice phenomena, and (b) ice cover.

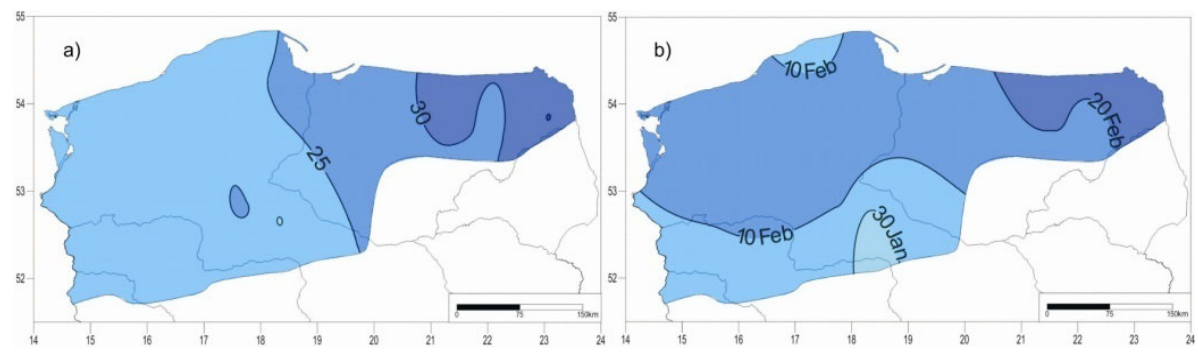

Fig. 5. Spatial differences in: (a) the thickness of ice cover, and (b) the date of occurrence of the maximum thickness of ice cover.
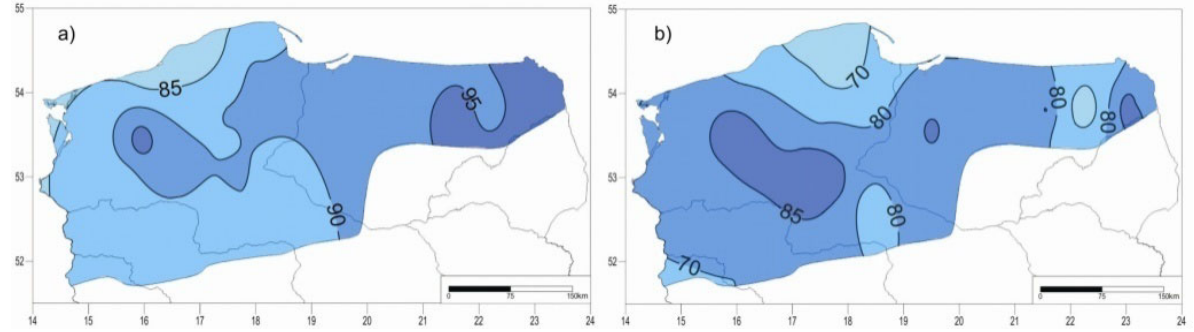

Fig. 6. Spatial differences in: (a) the degree of durability of ice cover, and (b) duration of ice cover divided by total period of phenomena.

The durability of ice cover is the shortest in the case of coastal lakes (about $80 \%$ ) and grows markedly eastwards to over 90\%; $c f$. Fig. 6a. There is no such regularity in the spatial variability of the share of ice cover in ice phenomena. In the case of the coastal lakes, it is under $80 \%$, and over $85 \%$ for the lakes in the central part of the Pomeranian Lakeland and the western part of the Mazurian Lakeland (Fig. 6b).

\subsection{Relations between lake ice phenology and the NAO}

The results obtained show that the intensity of the North Atlantic Oscillation in the winter season strongly affects the pattern of ice phenomena on Polish 
lakes. This is corroborated by both, the correlation of the $\mathrm{NAO}_{\text {DJFM }}$ index with the parameters of ice phenomena (Table 2), and the calculated differences between those parameters in the different $\mathrm{NAO}_{\text {DJFM }}$ phases and the average values (Figs. 7-14).

In a positive $\mathrm{NAO}_{\mathrm{DJFM}}$ phase, the dates of the end of ice phenomena and ice cover on the lakes under study are usually about 15 days later than the average, and the calculated differences in the dates are statistically significant $(p<0.05) ; c f$. Figs. 7 and 8 . The date of the end of those phases of ice phenology is even over 20 days later on lakes in the direct neighbourhood of the Baltic (coastal lakes). In a negative $\mathrm{NAO}_{\mathrm{DJFM}}$ phase, the ending dates come earlier than average, and statistically significant differences $(p<0.05)$ range from under 15 days in the west and east of the lakeland belt to over 20 days in the case of the coastal lakes.

The deviations of the ending dates of ice phenomena and ice cover in the different $\mathrm{NAO}_{\mathrm{DJFM}}$ phases from the average values cause also their duration
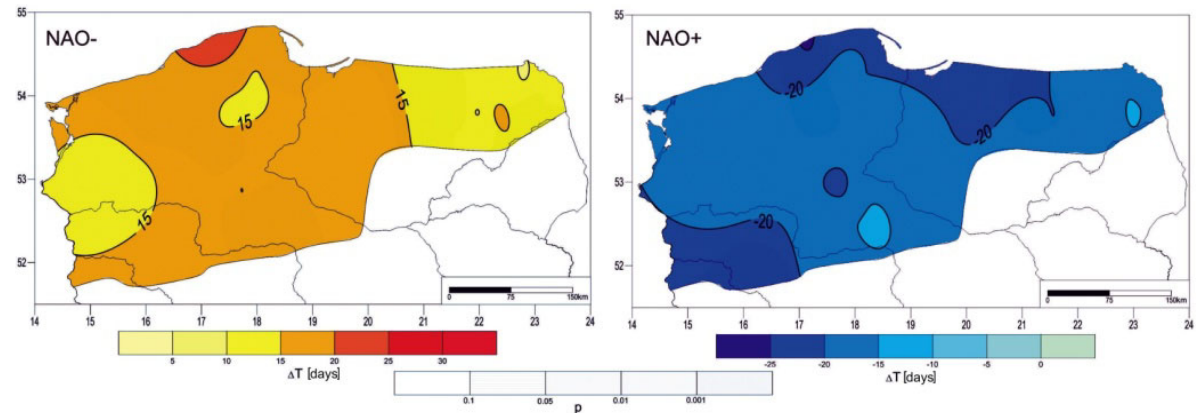

Fig. 7. Differences between the dates of the end of ice phenomena in a negative (NAO-) and a positive (NAO+) NAO phase, and the average values from the years 1961-2010; results of the test of the significance of the differences.

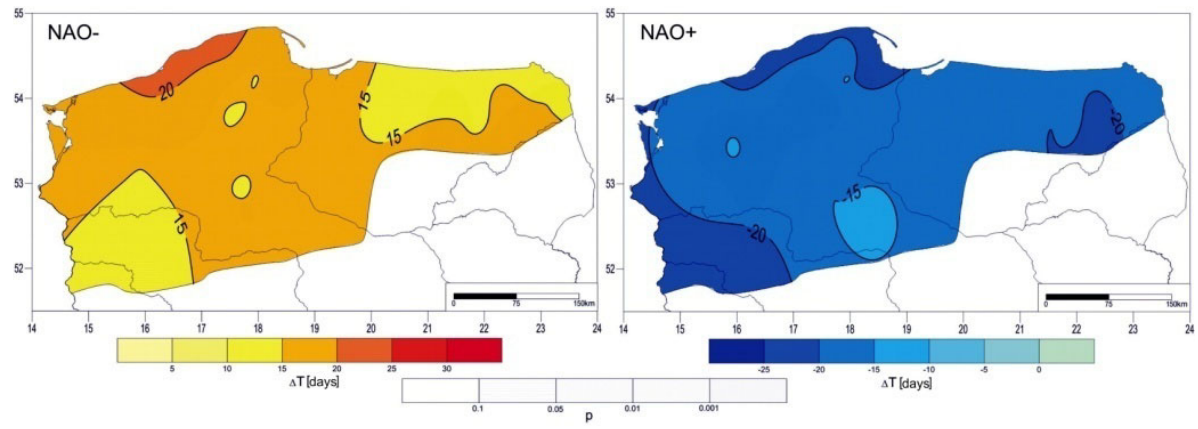

Fig. 8. Differences between the dates of the end of ice cover in a negative (NAO-) and a positive (NAO+) NAO phase, and the average values from the years 19612010; results of the test of the significance of the differences. 
$\frac{1}{0}$

\begin{tabular}{|c|c|c|}
\hline & 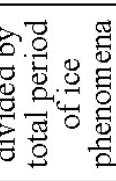 & 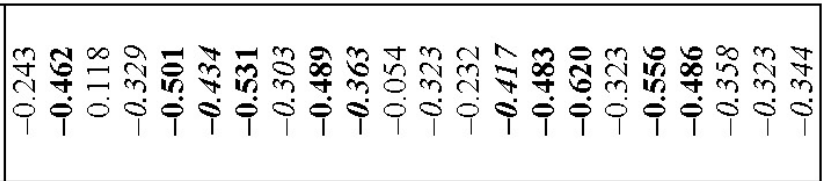 \\
\hline & 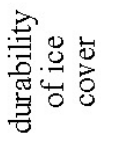 & 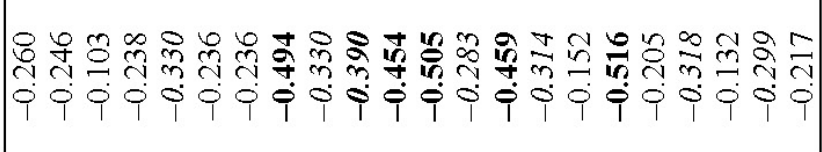 \\
\hline & 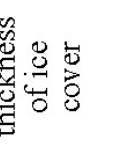 & 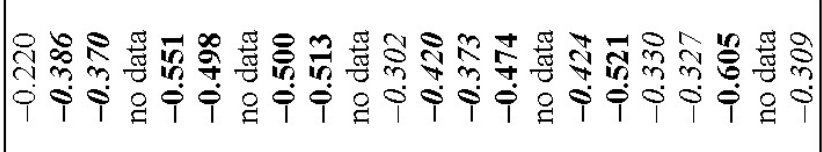 \\
\hline & 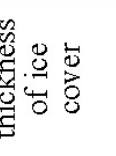 & 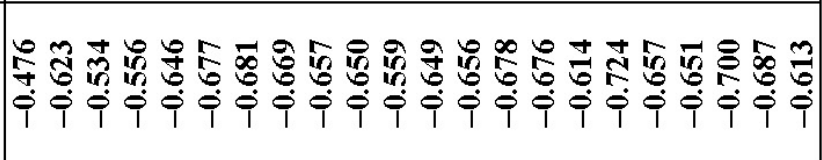 \\
\hline. & : & 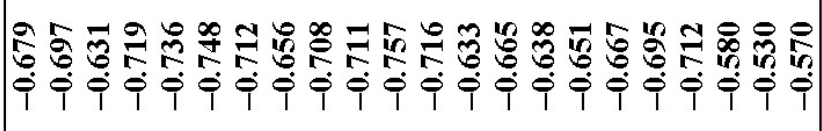 \\
\hline 胥 & 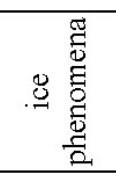 & 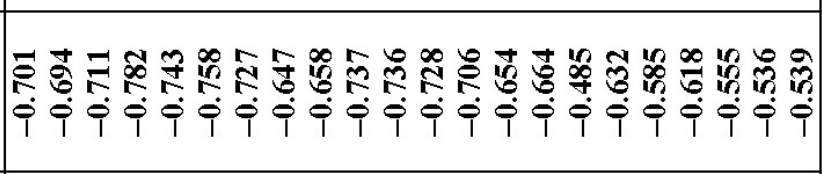 \\
\hline $\begin{array}{l}4 \\
0 \\
\end{array}$ & 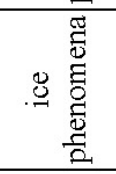 & 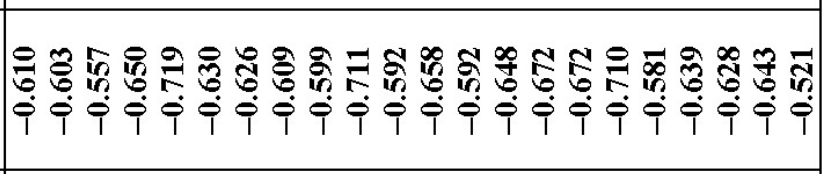 \\
\hline 1 & $\stackrel{\square}{0}$ & 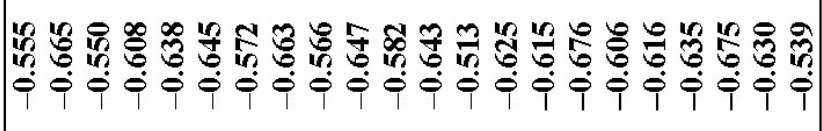 \\
\hline $\begin{array}{l}\vec{\circ} \\
\text { on } \\
. \Xi\end{array}$ & 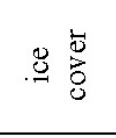 & 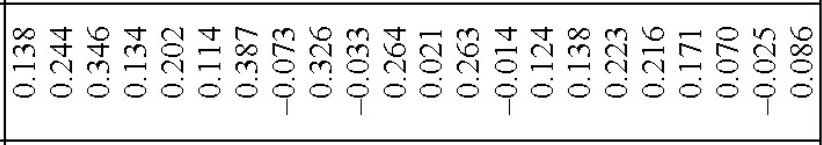 \\
\hline 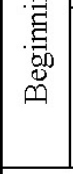 & 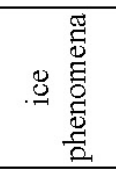 & 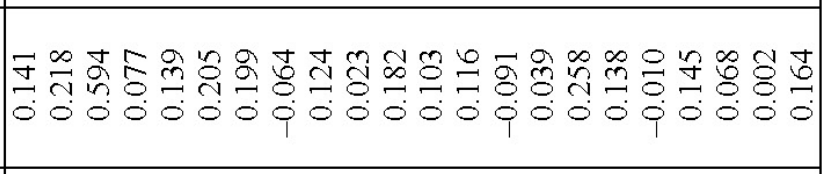 \\
\hline & 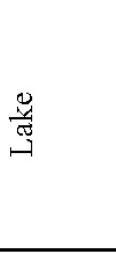 & 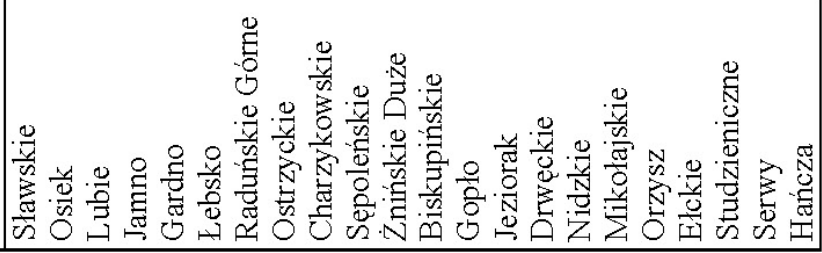 \\
\hline
\end{tabular}


in those phases to differ markedly, and statistically significantly $(p<0.05)$, from the means. In a positive $\mathrm{NAO}_{\text {DJFM }}$ phase, the duration of those characteristics is clearly shorter than the average, by more than 30 days in the case of the coastal lakes and those located in the western part of the country, dropping to under 20 days in the east. In a negative NAO ${ }_{\text {DJFM }}$ phase, the duration of ice phenomena, as well as of ice cover, is markedly longer than the average, from under 20 to over 30 days. The observed differences are statistically significant $(p<0.05)$, but more diversified spatially, although still greater in the case of the lakes in the west (especially the coastal ones) and smaller in the east - under 20 days; $c f$. Figs. 9 and 10.

Changes in the intensity of the North Atlantic Oscillation also affect the maximum thickness of ice cover and the date of its appearance. In a positive $\mathrm{NAO}_{\text {DJFM }}$ phase, the thickness is smaller, from under $10 \mathrm{~cm}$ on the lakes in the west of the country to over $10 \mathrm{~cm}$ in the eastern part of the lakeland zone; $c f$. Fig. 11. In a negative $\mathrm{NAO}_{\mathrm{DJFM}}$ phase, the maximum thickness fig-

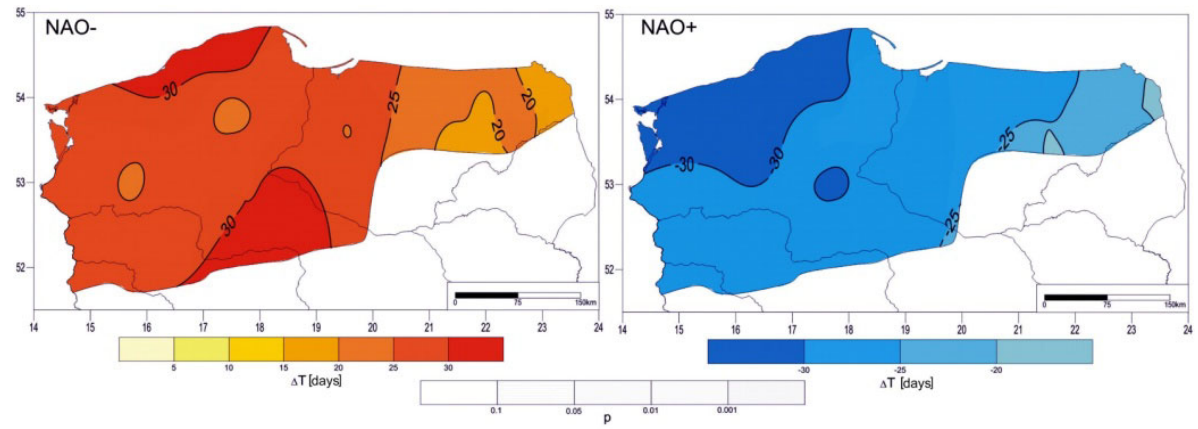

Fig. 9. Differences between the duration of ice phenomena in a negative (NAO-) and a positive (NAO+) NAO phase, and the average values from the years 19612010; results of the test of the significance of the differences.

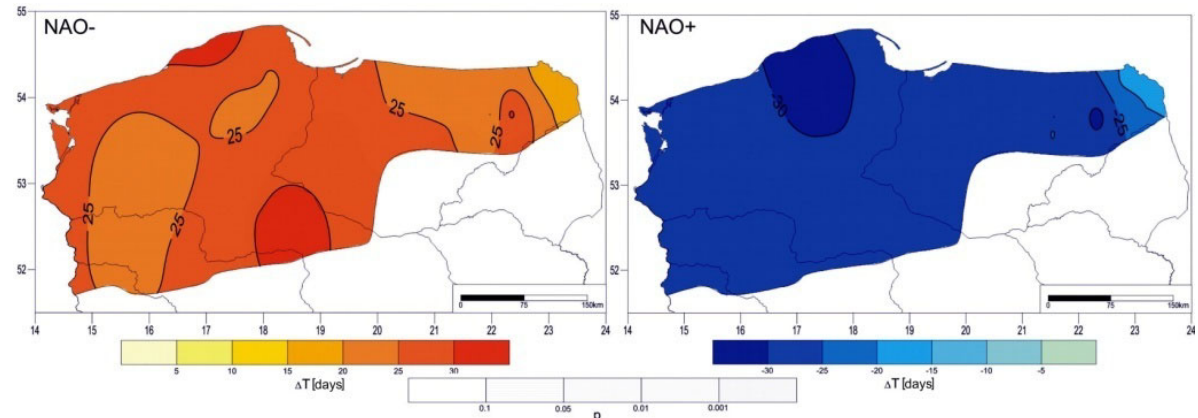

Fig. 10. Differences between the duration of ice cover in a negative (NAO-) and a positive (NAO+) NAO phase, and the average values from the years 1961-2010; results of the test of the significance of the differences. 


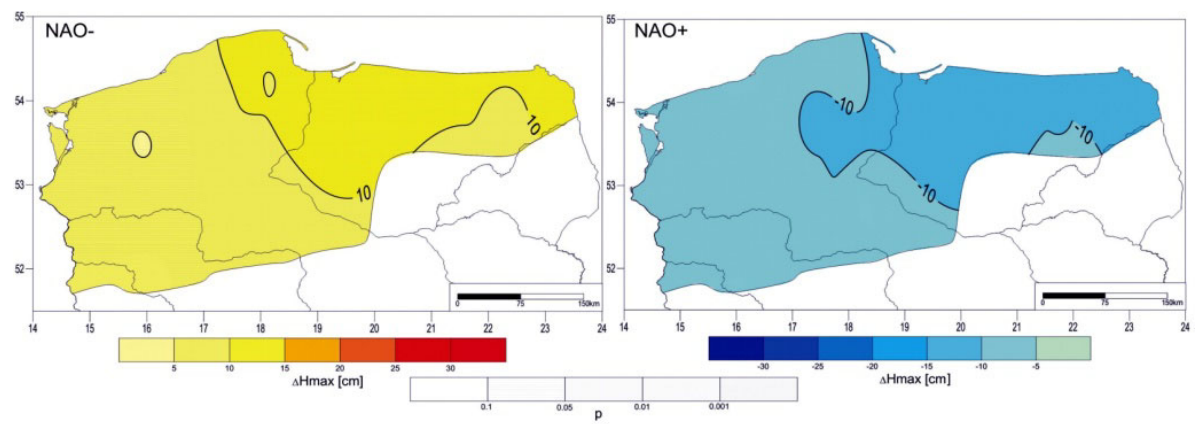

Fig. 11. Differences between the maximum thickness of ice cover in a negative (NAO-) and a positive (NAO+) NAO phase, and the average values from the years 1961-2010; results of the test of the significance of the differences.

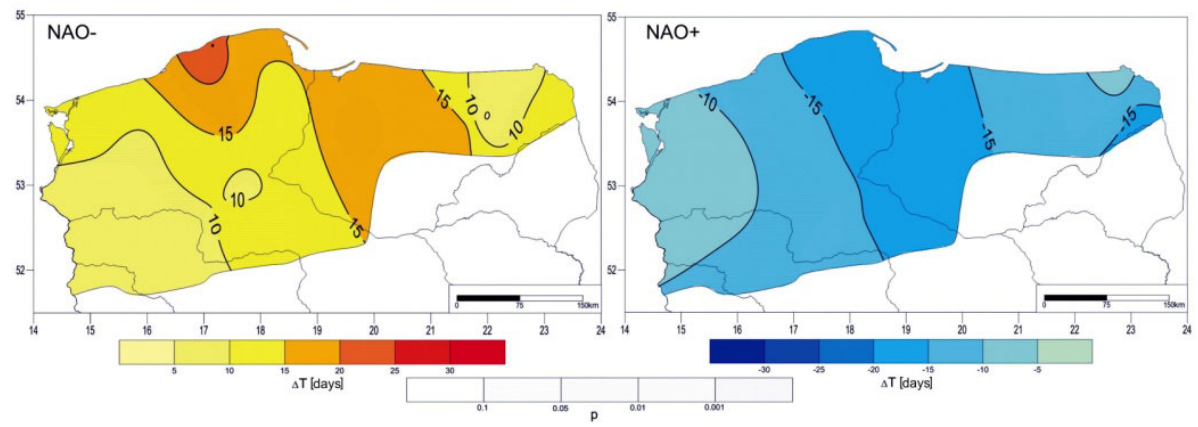

Fig. 12. Differences between the dates of occurrence of the maximum thickness of ice cover in a negative (NAO-) and a positive (NAO+) NAO phase, and the average values from the years 1961-2010; results of the test of the significance of the differences.

ures are greater, in the western part of the lakeland by about $5 \mathrm{~cm}$, although the observed differences from the average values are not statistically signifcant $(p>0.01)$. By contrast, the maximum thickness of ice cover on the lakes in the eastern part of the study area differs then in a statistically significant way $(p<0.05)$, by more than $10 \mathrm{~cm} ; c f$. Fig. 11.

Also the date of the appearance of the maximum thickness of ice cover changes significantly depending on the $\mathrm{NAO}_{\mathrm{DJFM}}$ phase. In a positive phase it comes from under 10 to over 15 days earlier than the average, and in a negative phase, later; $c f$. Fig. 12. The smallest deviations from average values, statistically not significant, can be observed on the lakes in the western and eastern parts of the lakeland belt, while the greatest, statistically significant $(p<0.05)$, differences occur on those in the central belt embracing the coastal lakes in the north and those of the Kujavia Lakeland in the south. In a negative $\mathrm{NAO}_{\text {DJFM }}$ phase, the date of the maximum thickness of ice cover on 
the coastal lakes is later than the average even by more than 20 days, and the observed differences are statistically significant $(p<0.01)$.

The durability of ice cover in a positive $\mathrm{NAO}_{\mathrm{DJFM}}$ phase is from less than $5 \%$ to over $10 \%$ smaller than the average, and the observed differences are usually not statistically significant; $c f$. Fig. 13 . In a negative $\mathrm{NAO}_{\text {DJFM }}$ phase the durability is greater. On the lakes in Poland's western part, however, this increase is not statistically significant, while in the central and eastern parts it is significant at $p<0.001$.

Also smaller in a positive $\mathrm{NAO}_{\text {DJFM }}$ phase is the share of the duration of ice cover in the entire period of occurrence of ice phenomena; $c f$. Fig. 14. The drop in this proportion observed then against average values varies from under 5 to over $15 \%$, only the greatest differences being statistically significant $(p<0.05)$. In turn, in a negative $\mathrm{NAO}_{\mathrm{DJFM}}$ phase this proportion grows and is $5-10 \%$ higher than the average.

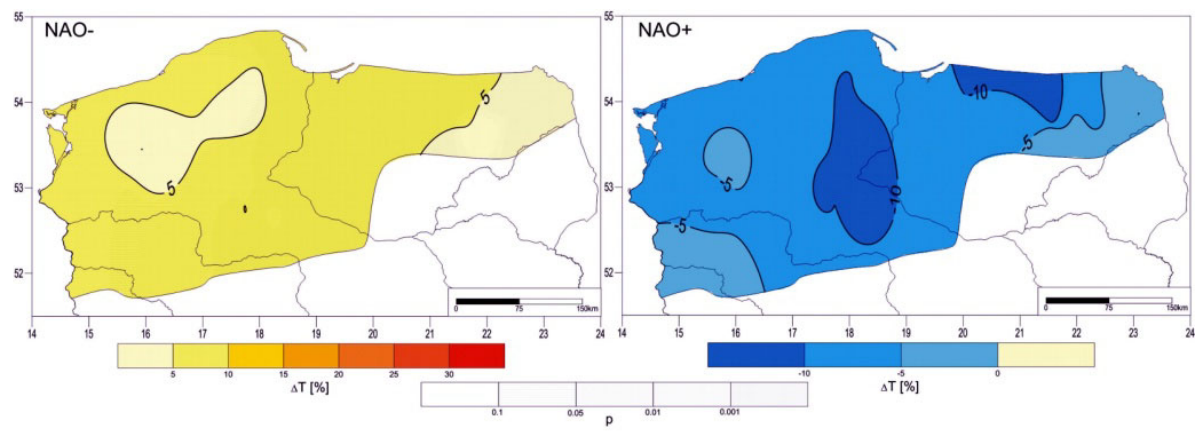

Fig. 13. Differences between the level of degree of durability of ice cover in a negative (NAO-) and a positive (NAO+) NAO phase, and the average values from the years 1961-2010; results of the test of the significance of the differences.

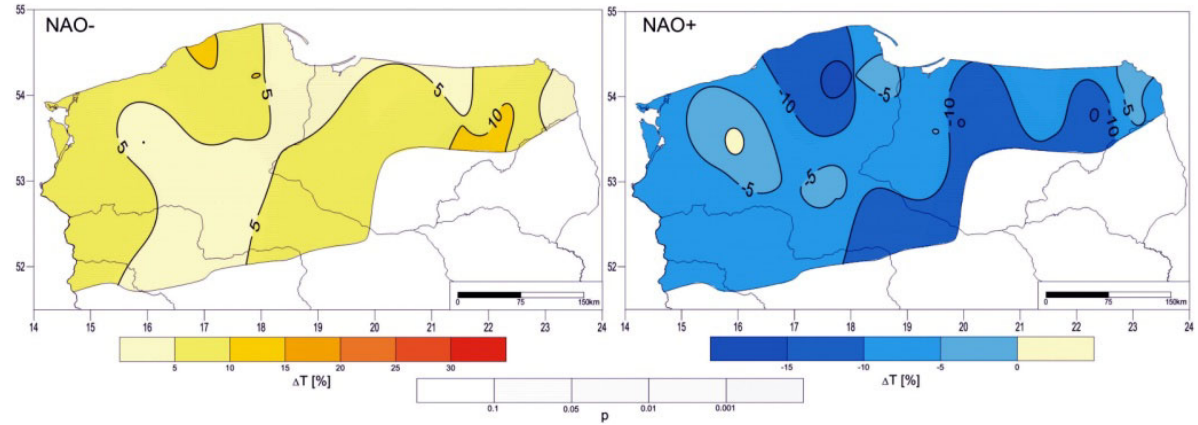

Fig. 14. Differences between the proportion of ice cover duration in the duration of ice phenomena in a negative (NAO-) and a positive $(\mathrm{NAO}+)$ NAO phase, and the average values from the years 1961-2010; results of the test of the significance of the differences. 
Coefficients of the correlation between the starting dates of ice phenomena and ice cover and the seasonal NAO indices

\begin{tabular}{|c|c|c|c|c|c|c|c|c|}
\hline Index NAO & \multicolumn{2}{|c|}{$\mathrm{NAO}_{\text {SON }}$} & \multicolumn{2}{|c|}{$\mathrm{NAO}_{\mathrm{OND}}$} & \multicolumn{2}{|c|}{$\mathrm{NAO}_{\mathrm{NDJ}}$} & \multicolumn{2}{|c|}{$\mathrm{NAO}_{\mathrm{DJF}}$} \\
\hline \multirow[b]{2}{*}{ Lake } & \multicolumn{2}{|c|}{ Beginning of } & \multicolumn{2}{|c|}{ Beginning of } & \multicolumn{2}{|c|}{ Beginning of } & \multicolumn{2}{|c|}{ Beginning of } \\
\hline & \begin{tabular}{|c|} 
ice \\
phenom- \\
ena
\end{tabular} & $\begin{array}{c}\text { ice } \\
\text { cover }\end{array}$ & $\begin{array}{c}\text { ice } \\
\text { phenom- } \\
\text { ena }\end{array}$ & $\begin{array}{c}\text { ice } \\
\text { cover }\end{array}$ & \begin{tabular}{|c|} 
ice \\
phenom- \\
ena
\end{tabular} & $\begin{array}{c}\text { ice } \\
\text { cover }\end{array}$ & $\begin{array}{c}\text { ice } \\
\text { phenom- } \\
\text { ena }\end{array}$ & $\begin{array}{l}\text { ice } \\
\text { cover }\end{array}$ \\
\hline Sławskie & 0.284 & 0.344 & 0.322 & 0.408 & 0.355 & 0.397 & 0.132 & $1.14 J$ \\
\hline Osiek & 0.335 & 0.238 & 0.452 & 0.369 & 0.447 & 0.481 & 0.225 & 0.171 \\
\hline Lubie & 106 & 085 & 0.418 & 0.342 & 0.684 & 0.547 & .546 & 0.291 \\
\hline Jamno & 0.231 & 0.257 & 0.313 & 0.298 & 0.319 & 0.367 & 0.105 & 0.231 \\
\hline Gar & 0.256 & 0.167 & 0.275 & 0.291 & 0.334 & 0.421 & 0.109 & .205 \\
\hline Lebs & 0.264 & 0.179 & 0.356 & 0.239 & 0.374 & 0.316 & 0.176 & 133 \\
\hline Raduńsk & 0.181 & 0.176 & 0.231 & 0.270 & 0.371 & 0.458 & 0.176 & 0.303 \\
\hline Ostrzyckie & 0.290 & 0.316 & 0.258 & 0.294 & 0.225 & 0.252 & -0.008 & 0.022 \\
\hline Charzykowskie & 0.323 & 0.305 & 0.409 & 0.436 & 0.424 & 0.545 & 0.122 & 0.247 \\
\hline Sępol & 0.279 & 0.279 & 0.376 & 0.343 & 0.308 & 0.242 & 0.023 & -0.024 \\
\hline Żnińskie & 0.152 & 0.214 & 0.235 & 0.346 & 29 & 0.420 & 52 & 0.215 \\
\hline Bisku & 0.253 & 0.285 & 0.373 & 0.349 & 0.353 & 0.295 & 0.112 & 0.073 \\
\hline Gopło & 0.290 & 0.269 & 0.385 & 0.356 & 0.370 & 0.409 & 0.056 & 0.158 \\
\hline Jeziorak & 0.160 & 0.291 & 0.166 & 0.368 & 0.074 & 0.247 & -0.053 & 0.035 \\
\hline Drwęckie & 0.016 & 0.242 & 0.120 & 0.262 & 0.154 & 0.275 & 0.066 & 0.046 \\
\hline Nidzkie & 0.246 & 0.242 & 0.377 & 0.349 & 0.429 & 0.358 & 0.230 & 0.145 \\
\hline Mikołajskie & 0.215 & 0.264 & 0.294 & 0.345 & 0.355 & 0.373 & 0.129 & 0.173 \\
\hline Orzysz & 0.318 & 0.346 & 0.277 & 0.430 & 0.197 & 0.478 & -0.012 & 0.241 \\
\hline Ełckie & 0.330 & 0.326 & 0.344 & 0.375 & 0.292 & 0.349 & 0.112 & 0.128 \\
\hline Studzie & 0.282 & 0.337 & 0.270 & 0.348 & 0.255 & 0.318 & 0.106 & 0.111 \\
\hline Serwy & 0.304 & 0.355 & 0.261 & 0.304 & 0.182 & 0.260 & -0.007 & -0.032 \\
\hline Hańcza & 0.291 & 0.216 & 0.362 & 0.283 & 0.326 & 0.271 & 0.122 & 0.055 \\
\hline
\end{tabular}

Note: Significance of correlation coefficients at the levels: $p<0.05, p<\boldsymbol{0 . 0 1}$, $p<\mathbf{0 . 0 0 1}$.

Out of the parameters under study, only the starting dates of ice phenomena and ice cover do not show any relation with the intensity of the North Atlantic Oscillation as expressed by the $\mathrm{NAO}_{\mathrm{DJFM}}$ index. Those dates usually fall in December; hence, the lack of a relation with the index determined for a later period is understandable. However, an analysis showed there to be a connection between the starting dates of ice phenomena and ice cover and $\mathrm{NAO}$ indices calculated for earlier seasons, especially $\mathrm{NAO}_{\mathrm{OND}}$ and $\mathrm{NAO}_{\mathrm{NDJ}}$. 
It is statistically significant $(p<0.05)$ for all the lakes with the exception of Drwęckie (Table 3). Twelve of the examined lakes also show statistically significant relations between the dates of appearance of ice phenomena and ice cover and the $\mathrm{NAO}_{\mathrm{SON}}$ index for the September-November period $(p=0.05)$.

In the study period, the lowest value of the $\mathrm{NAO}_{\text {DJFM }}$ index was recorded in 1969 (-4.89), and the highest in 1989 (5.08). In those years extremely different parameters of ice phenomena were observed on the lakes. In 1969 the average duration of ice cover was 113 days (the longest one, 136 days, persisting on Lake Sępoleńskie), as against a mere 16 days in 1989, while on Żnińskie Duże, Sławskie, and Gopło it was not recorded at all that year. The mean thickness of maximum ice cover in 1969 was $43.4 \mathrm{~cm}$ as against a mere $10.2 \mathrm{~cm}$ in 1989. It should be emphasized that in the entire multi-year period under analysis the year 1969 was the one when the maximum thickness of ice was recorded; in two cases (Lakes Studziennicze and Mikołajskie) it reached $65 \mathrm{~cm}$.

\section{DISCUSSION}

The duration of ice phenology in midland water bodies basically grows with the geographical latitude (Livingstone et al. 2009). However, this dependence can be modified by macro-scale circulation (which variously affects climatic conditions in different parts of the world, depending on its type), and by individual characteristics of lakes (Choiński and Ptak 2012), their surroundings (Choiński et al. 2013), and the local circulation (Blenckner et al. 2004).

Ice phenology is directly connected with the thermal balance of a lake. Over the last decades, there has been a more rapid increase in air temperature in the spring period (Benson et al. 2012). This translates into higher temperatures of lake water. In the case of Polish lakes, it is precisely in spring that it grows the fastest, $0.2-0.5^{\circ} \mathrm{C}$ decade $^{-1}$ (Skowron 2011). A consequence has been a quicker disappearance of ice cover, and thus its shorter duration. As a result, the tendencies of change in the pattern of ice phenology recorded for Polish lakes in the second half of the 20th century are mostly downward ones (Pasławski 1982, Marszelewski and Skowron 2006, Choiński et al. 2014).

The relations between the temperatures of air and water are closely associated regionally with the macro-scale circulation of the atmosphere (Dabrowski et al. 2004, Livingstone et al. 2010). The analysis of NAO-related changes in the thermal conditions of lakes in Poland conducted by Wrzesiński et al. (2015) showed considerable deviations from mean values (both $1{ }^{\circ} \mathrm{C}$ lower and higher, depending on the circulation phase), and those deviations were readily visible in spring, i.e., in the period of ice cover destruction. 
In the case of European lakes, also their ice regime shows strong relations with the NAO circulation (Dokulil 2013). When analysing the pattern of ice phenomena on the largest lake in England (Windermere), George (2007) found that this circulation type had greatly influenced ice formation on it for over 30 years, and the link between this phenomenon and the NAO accounted for $50 \%$ of inter-year changes. In the case of Lake Erken located in the east of Sweden, an earlier decay of its ice cover was closely related with a high NAO index (Blenckner and Chen 2003). In turn, Maher et al. (2005) analysed two winter seasons in the different NAO phases on Lake Vendyurskoe in the northern part of Russia and noted that ice cover tended to be thicker in a negative phase, while its duration did not differ significantly in the two periods analysed. The relations between lake ice phenology and the NAO have also been documented for other regions of the Northern Hemisphere, e.g., in Siberia (Livingstone 1999) or North America (Livingstone 2000). The ice cover of the North American Great Lakes has a linear connection with the NAO and is thicker or thinner depending on its phase (Bai et al. 2012).

In the case of Polish lakes, all the examined characteristics of ice phenology respond to variations in the pattern of macro-scale circulation by deviating from the mean values. This is especially significant for the duration of ice cover, which isolates a lake from the influence of external factors, and this, as has been mentioned in the Introduction, completely changes the operation of the given ecosystem. The inter-year variability of this characteristic in Poland is considerable and amounts to over a month, depending on the phase and intensity of the NAO.

The NAO is an essential but not the only element responsible for the pattern of lake ice phenology in this part of Europe. This is indicated by the spatial differences in conditions of lake ice phenology in Poland reported in this paper. Karetnikov and Naumenko (2008) came to similar conclusions in the case of Lake Ladoga; they found a connection between the NAO and ice phenology which was absent when ice cover exhibited extreme characteristics. In principle, the severity of ice phenomena on Polish lakes grows eastwards. This has been observed by, e.g., Girjatowicz (2003) for four coastal lakes. Thus, what should be taken as the basic feature influencing the length of the ice season on the lakes under study is their location. Departures from this rule are connected with morphometric characteristics of individual lakes and local conditions. Of key significance for lakes located in the lowland zone are the former, and the effect of the surroundings on the pattern of lake ice phenology is especially readily visible in mountain lakes, as corroborated by the research conducted, among others, by Novikmec et al. (2013).

The most important morphometric feature of lakes in terms of ice phenology is their depth, because it decides about the amount of accumulated 
warmth and hence about the time needed for cooling and freezing (Korhonen 2006). However, in the case of the lakes analysed here, this feature is not readily visible. A later start of the appearance of ice cover was recorded in both, one of the deepest lakes (e.g., Raduńskie Górne) and one of the shallowest ones (e.g., Gopło). This situation illustrates the complexity of overlapping processes and environmental features, the resultants of which are the formation and disappearance of ice in lakes.

The transformation occurring in the conditions of the ice phenology of lakes affects their operation throughout the year, not only in winter. There are many works that connect the physico-chemical conditions of lakes (Leppäranta et al. 2003, Witek and Jarosiewicz 2010, Mihu-Pintilie et al. 2014) and biological ones (Pettersson 1990, Hurst 2007, Vehmaa and Salonen 2009) with their ice phenology. The effect (or its absence) of ice phenology on living conditions is also observed with reference to lakes in Poland (Toporowska et al. 2010, Wojciechowska and Lenard 2014, Sienkiewicz and Gąsiorowski 2014, Messyasz et al. 2015, Pełechata et al. 2015). The considerable differences in the duration of ice cover may change the species composition of both flora and fauna, which in consequence can lead to the replacement of present species by other organisms. As has been observed by Ptak (2013), the disappearance of the most endangered species would be especially detrimental.

\section{CONCLUSIONS}

The results presented in this paper concerning the pattern of lake ice phenology in Poland against changes in the intensity of the North Atlantic Oscillation are similar to those established earlier for lakes of the Northern Hemisphere. In the different NAO phases, wide, statistically significant differences can be observed between the values of ice phenology parameters (e.g., those concerning shore ice, ice cover, its thickness, etc.) and the mean figures. Of special importance are the considerable deviations from the duration of ice cover - an element which, by isolating water masses from external factors and processes, has the strongest influence on the operation of lakes. Also established were spatial differences in the scale of the effect of the NAO on the conditions of ice phenology of individual lakes. Like the studies by other authors cited here, it is a proof of the complexity of this issue. The effect of the NAO circulation can be stronger or weaker, depending on individual morphometric characteristics of lakes.

The results obtained can be a valuable starting point for further research on lake ice phenology. In the future it might be advisable to build models describing variations in the characteristics (both chemical-physical and biological) of lake ecosystems by accommodating changes in their ice regimes. With detailed multi-year information on the pattern of lake ice phenology for 
a large set of objects, it will be possible to formulate general regularities concerning lakes in this part of Europe.

\section{References}

Bai, X., J. Wang, C. Sellinger, A. Clites, and R. Assel (2012), Interannual variability of Great Lakes ice cover and its relationship to NAO and ENSO, J. Geophys. Res. 117, C3, C03002, DOI: 10.1029/2010JC006932.

Bednorz, E. (2011), Synoptic conditions of the occurrence of snow cover in central European lowlands, Int. J. Climatol. 31, 8, 1108-1118, DOI: 10.1002/ joc. 2130 .

Benson, B.J., J.J. Magnuson, O.P. Jensen, V.M. Card, G. Hodgkins, J. Korhonen, D.M. Livingstone, K.M. Stewart, G.A. Weyhenmeyer, and N.G. Granin (2012), Extreme events, trends, and variability in Northern Hemisphere lake-ice phenology (1855-2005), Climatic Change 112, 2, 299-323, DOI: 10.1007/s10584-011-0212-8.

Blenckner, T., and D. Chen (2003), Comparison of the impact of regional and North Atlantic atmospheric circulation on an aquatic ecosystem, Climate Res. 23, 2, 131-136, DOI: 10.3354/cr023131.

Blenckner, T., M. Järvinen, and G.A. Weyhenmeyer (2004), Atmospheric circulation and its impact on ice phenology in Scandinavia, Boreal Environ. Res. 9, 5, 371-380.

Brown, L.C., and C.R. Duguay (2010), The response and role of ice cover in lakeclimate interactions, Prog. Phys. Geog. 34, 5, 671-704, DOI: 10.1177/ 0309133310375653.

Castro, A., M.I. Vidal, A.I. Calvo, M. Fernández-Raga, and R. Fraile (2011), May the NAO index be used to forecast rain in Spain? Atmósfera 24, 3,251-265.

Choiński, A., and M. Ptak (2012), Variation in the ice cover thickness on Lake Samołęskie as a result of underground water supply, Limnol. Rev.12, 3, 133-138, DOI: 10.2478/v10194-012-0053-5.

Choiński, A., M. Ptak, and A. Strzelczak (2013), Areal variation in ice cover thickness on lake Morskie Oko (Tatra Mountains), Carpat. J. Earth Environ. Sci. 8, 3, 97-102.

Choiński, A., M. Ptak, and R. Skowron (2014), Trends to changes in ice phenomena in Polish lakes in the years 1951-2010, Prz. Geogr. 86, 1, 23-40, DOI: 10.7163/PrzG.2014.1.2 (in Polish).

Dąbrowski, M., W. Marszelewski, and R. Skowron (2004), The trends and dependencies between air and water temperatures in lakes in northern Poland in 1961-2000, Hydrol. Earth Syst. Sci. 8, 1, 79-87, DOI: 10.5194/hess-8-792004. 
Dokulil, M.T. (2013), Impact of climate warming on European inland waters, Inland Waters 4, 1, 27-40, DOI: 10.5268/IW-4.1.705.

Futter, M.N. (2003), Patterns and trends in Southern Ontario lake ice phenology, Environ. Monit. Assess. 88, 1-3, 431-444, DOI: 10.1023/A:1025549913965.

George, D.G. (2007), The impact of the North Atlantic Oscillation on the development of ice on Lake Windermere, Climatic Change 81, 3-4, 455-468, DOI: 10.1007/s10584-006-9115-5.

Gerten, D., and R. Adrian (2000), Climate-driven changes in spring plankton dynamics and the sensitivity of shallow polymictic lakes to the North Atlantic Oscillation, Limnol. Oceanogr. 45, 5, 1058-1066, DOI: 10.4319/1o.2000. 45.5.1058.

Girjatowicz, J.P. (2003), The influence of the North Atlantic Oscillation on ice conditions in coastal lakes of the Southern Baltic Sea, Ann. Limnol. - Int. J. Limnol. 39, 1, 71-80, DOI: 10.1051/limn/2003007.

Heape, R., J. Hirschi, and B. Sinha (2013), Asymmetric response of European pressure and temperature anomalies to NAO positive and NAO negative winters, Weather 68, 3, 73-80, DOI: 10.1002/wea.2068.

Hurrell, J. (1995), The Climate Data Guide: Hurrell North Atlantic Oscillation (NAO) Index, National Center for Atmospheric Research, Boulder, USA, https:/climatedataguide.ucar.edu/climate-data/hurrell-north-atlanticoscillation-nao-index-station-based, last modified 20 October 2015.

Hurst, T.P. (2007), Causes and consequences of winter mortality in fishes, J. Fish Biol. 71, 2, 315-345, DOI: 10.1111/j.1095-8649.2007.01596.x.

Jensen, O.P., B.J. Benson, J.J. Magnuson, V.M. Card, M.N. Futter, P.A. Soranno, and K.M. Stewart (2007), Spatial analysis of ice phenology trends across the Laurentian Great Lakes region during a recent warming period, Limnol. Oceanogr. 52, 5, 2013-2026, DOI: 10.4319/lo.2007.52.5.2013.

Karetnikov, S.G., and M.A. Naumenko (2008), Recent trends in Lake Ladoga ice cover, Hydrobiologia 599, 1, 41-48, DOI: 10.1007/s10750-007-9211-1.

Korhonen, J. (2006), Long-term changes in lake ice cover in Finland, Nord. Hydrol. 37, 4-5, 347-363, DOI: 10.2166/nh.2006.019.

Leppäranta, M. (2014), Interpretation of statistics of lake ice time series for climate variability, Hydrol. Res. 45, 4-5, 673-683, DOI: 10.2166/nh.2013.246.

Leppäranta, M., A. Reinart, A. Erm, H. Arst, M. Hussainov, and L. Sipelgas (2003), Investigation of ice and water properties and under-ice light fields in fresh and brackish water bodies, Nord. Hydrol. 34, 3, 245-266, DOI: 10.2166/ nh.2003.015.

Livingstone, D.M. (1999), Ice break-up on southern Lake Baikal and its relationship to local and regional air temperatures in Siberia and to the North Atlantic Oscillation, Limnol. Oceanogr. 44, 6, 1486-1497, DOI: 10.4319/1o.1999.44. 6.1486 . 
Livingstone, D.M. (2000), Large-scale climatic forcing detected in historical observations of lake ice break-up, Verh. Int. Verein. Theor. Angew. Limnol. 27, 5, 2775-2783.

Livingstone, D.M., R. Adrian, T. Blenckner, G. George, and G.A. Weyhenmeyer (2009), Lake ice phenology. In: G. George (ed.), The Impact of Climate Change on European Lakes, Aquatic Ecology Series, Vol. 4, Springer, Dordrecht, 51-61, DOI: 10.1007/978-90-481-2945-4_4.

Livingstone, D.M., R. Adrian, L. Arvola, T. Blenckner, M.T. Dokulil, R.E. Hari, G. George, T. Jankowski, M. Järvinen, E. Jennings, P. Nõges, T. Nõges, D. Straile, and G.A. Weyhenmeyer (2010), Regional and supra-regional coherence in limnological variables. In: G. George (ed.), The Impact of Climate Change on European Lakes, Aquatic Ecology Series, Vol. 4, Springer, Dordrecht, 311-337, DOI: 10.1007/978-90-481-2945-4_17.

Maher, O.A., C. Bertacchi Uvo, and L. Bengtsson (2005), Comparison between two extreme NAO winters and consequences on the thermal regime of Lake Vendyurskoe, Karelia, J. Hydrometeorol. 6, 5, 775-783, DOI: 10.1175/ JHM449.1.

Majewski, W. (2007), Flow in open channels under the influence of ice cover, Acta Geophys. 55, 1, 11-22, DOI: 10.2478/s11600-006-0041-8.

Marszelewski, W., and R. Skowron (2006), Ice cover as an indicator of winter air temperature changes: case study of the Polish Lowland lakes, Hydrol. Sci. J. 51, 2, 336-349, DOI: 10.1623/hysj.51.2.336.

Messyasz, B., M. Gąbka, J. Barylski, G. Nowicki, Ł. Lamentowicz, A. GoździckaJózefiak, A. Rybak, R. Dondajewska, and L. Burchardt (2015), Phytoplankton, culturable bacteria and their relationships along environmental gradients in a stratified eutrophic lake, Carpath. J. Earth Environ. Sci. 10, 1, 41-52.

Mihu-Pintilie, A., G. Romanescu, and C. Stoleriu (2014), The seasonal changes of the temperature, $\mathrm{pH}$ and dissolved oxygen in the Cuejdel Lake, Romania, Carpathian J. Earth Environ. Sci. 9, 2, 113-123.

Novikmec, M., M. Svitok, D. Kočický, F. Šporka, and P. Bitušík (2013), Surface water temperature and ice cover of Tatra Mountains lakes depend on altitude, topographic shading, and bathymetry, Arct. Antarct. Alp. Res. 45, 1, 77-87, DOI: 10.1657/1938-4246-45.1.77.

Pasławski, Z. (1982), Ice conditions of the lakes in Poland, Prz. Geof. 27, 1-2, 79-92 (in Polish).

Pełechata, A., M. Pełechaty, and A. Pukacz (2015), Winter temperature and shifts in phytoplankton assemblages in a small Chara-lake, Aquat. Bot. 124, 10-18, DOI: 10.1016/j.aquabot.2015.03.001.

Pettersson, K. (1990), The spring development of phytoplankton in Lake Erken: species composition, biomass, primary production and nutrient conditions a review, Hydrobiologia 191, 1, 9-14, DOI: 10.1007/BF00026033. 
Pociask-Karteczka, J. (2006), River hydrology and the North Atlantic Oscillation: A general review, Ambio 35, 6, 312-314, DOI: 10.1579/05-S-114.1.

Ptak, M. (2013), Variability of temperature and ice phenomena on Łebsko and Gardno lakes, Parki Narodowe i Rezerwaty Przyrody 32, 2, $45-55$ (in Polish).

Scaife, A.A., C.K. Folland, L.V. Alexander, A. Moberg, and J.R. Knight (2008), European climate extremes and the North Atlantic Oscillation, J. Climate 21, 1, 72-83, DOI: 10.1175/2007JCLI1631.1.

Sharov, A.N., N.A. Berezina, L.E. Nazarova, T.N. Poliakova, and T.A. Chekryzheva (2014), Links between biota and climate-related variables in the Baltic region using Lake Onega as an example, Oceanologia 56, 2, 291-306, DOI: 10.5697/oc.56-2.291.

Sienkiewicz, E., and M. Gąsiorowski (2014), Changes in the trophic status of three mountain lakes - natural or anthropogenic process? Pol. J. Environ. Stud. 23, 3, 875-892.

Skowron, R. (2011), The Differentiation and the Changeability of Chosen Elements of the Thermal Regime of Water in Lakes on Polish Lowland, Wyd. Nauk. Uniwersytetu Mikołaja Kopernika, Toruń, 245 pp. (in Polish).

Soja, A.-M., K. Kutics, K. Maracek, G. Molnár, and G.Soja (2014), Changes in ice phenology characteristics of two Central European steppe lakes from 1926 to 2012 - influences of local weather and large scale oscillation patterns, Climatic Change 126, 1, 119-133, DOI: 10.1007/s10584-014-1199-8.

Thomson, D.J. (2009), Climate change: Shifts in season, Nature 457, 7228, 391-392, DOI: 10.1038/457391a.

Toporowska, M., B. Pawlik-Skowrońska, D. Krupa, and R. Kornijów (2010), Winter versus summer blooming of phytoplankton in a shallow lake: Effect of hypertrophic conditions, Pol. J. Ecol. 58, 1, 3-12.

Vehmaa, A., and K. Salonen (2009), Development of phytoplankton in Lake Pääjärvi (Finland) during under-ice convective mixing period, Aquat. Ecol. 43, 3, 693-705, DOI: 10.1007/s10452-009-9273-4.

Weyhenmeyer, G.A. (2009), Do warmer winters change variability patterns of physical and chemical lake conditions in Sweden? Aquat. Ecol. 43, 3, 653-659, DOI: $10.1007 / \mathrm{s} 10452-009-9284-1$.

Witek, Z., and A. Jarosiewicz (2010), The oxygen budget of two closed, dimictic lakes in the vicinity of Bytów (West Pomeranian Lake District, northern Poland), Oceanol. Hydrobiol. Stud. 39, 2, 135-145, DOI: 10.2478/v10009010-0022-8.

Wojciechowska, W., and T. Lenard (2014), Effect of extremely severe winters on under-ice phytoplankton development in a mesotrophic lake (Eastern Poland), Oceanol. Hydrobiol. Stud. 43, 2: 147-153, DOI: 10.2478/s13545014-0127-x. 
Wrzesiński, D., and R. Paluszkiewicz (2011), Spatial differences in the impact of the North Atlantic Oscillation on the flow of rivers in Europe, Hydrol. Res. 42, 1, 30-39, DOI: 10.2166/nh.2010.077.

Wrzesiński, D., M. Ptak, and A. Baczyńska (2013), Effect of the North Atlantic Oscillation on ice phenomena on selected lakes in Poland over the years 19612010, Quaest. Geogr. 32, 3, 119-128, DOI: 10.2478/quageo-2013-0020.

Wrzesiński, D., A. Choiński, and M. Ptak (2015) Effect of the North Atlantic Oscillation on the thermal characteristics of lakes in Poland, Acta Geophys. 63, 3, 863-883, DOI: 10.1515/acgeo-2015-0001.

Received 21 January 2015

Received in revised form 11 May 2015

Accepted 22 May 2015 